\title{
LOKALITAS STRUKTUR KONSTRUKSI \\ RUMAH TRADISIONAL SABU DI KAMPUNG ADAT NAMATA, NTT
}

\author{
Yohanes Wilhelmus Dominikus Kapilawi ${ }^{1}$, Antariksa² ${ }^{2}$, Agung Murti Nugroho ${ }^{3}$ \\ ${ }^{1}$ Mahasiswa Fakultas Teknik Program Magister Arsitektur Lingkungan Binaan Jurusan Arsitektur \\ Universitas Brawijaya Malang \\ $2 \& 3$ PM-Arsitektur Lingkungan Binaan Fakultas Teknik Universitas Brawijaya \\ mus.kapilawi@gmail.com
}

\begin{abstract}
ABSTRAK
Pengaruh lingkungan dan interaksi sosial antara satu kelompok dengan kelompok yang lain menghasilkan aturan yang terwujud dalam sebuah tatanan nilai - nilai aturan budaya, tertuang dalam wujud fisik yang tentunya selalu menyesuaikan terhadap lingkungan sekitarnya. Aturan nilai budaya dalam wujud fisik menghasilkan kebiasaan atau tradisi, dalam wujud kearifan berarsitektur terhadap bagian - bagian elemen konstruksinya dalam pemanfaatan teknologi berupa peralatan, sistem sambungan dan material konstruksi setempat. Kearifan lokal ini tentunya memiliki nilai tradisi dan aturan yang selalu menjaga keseimbangan antara alam tempat hunian. Kampung adat Namata merupakan sebuah perkampungan adat tertua di Pulau Sabu yang kaya akan nilai budaya, sejarah, keragaman suku dan arsitektur rumah tradisionalnya. Arsitektur rumah tradisional Sabu (Ammu Hawu) merupakan salah satu cerminan lokalitas yang memiliki tatanan aturan nilai budaya setempat dan memiliki nilai keseimbangan antara lingkungan dan tempat tinggalnya. Lokalitas arsitekturnya terlihat dari struktur konstruksi yang ada pada setiap bagian - bagian elemen konstruksi Ammu Rahi Hawu. Objek rumah ini yang dijadikan sebagai objek untuk diteliti terhadap bagian - bagian elemen struktur konstruksinya terkait unsur - unsur nilai budaya setempat. Tujuan penelitian ini untuk mengidentifikasikan dan menganalisis lokalitas terhadap bagian - bagian elemen struktur konstruksi. Penelitian menggunakan metode deskriptif kualitatif dengan pendekatan etnografi, dengan kriteria pemilihan sampel penelitiannya, yakni terhadap bangunan yang merupakan bagian yang dikategorikan sebagai rumah adat serta karakteristik struktur konstruksi sesuai fungsi bangunan.
\end{abstract}

Kata kunci : Lokalitas, Struktur Konstruksi, Rumah Tradisional.

\section{Pendahuluan}

Kondisi geografis lingkungan pada Pulau Sabu dengan iklim Savana, yang memiliki intensitas jumlah panas yang panjang dan curah hujan yang begitu rendah. Memungkinkan kehidupan yang ada pada alam lingkungan tersebut untuk harus dapat beradaptasi dengan kondisi tersebut, dengan alam vegetasi yang sesuai alam lingkungannya. Kehidupan masyarakat yang ada pada lingkungan tersebut dituntut untuk dapat menyesuaikan fisik bangunannya terhadap fisik lingkungan. Nampak jelas bangunan - bangunan rumah tradisionalnya yang memanfaatkan material konstruksi bangunannya dari vegetasi yang tersedia disekitarnya dan sudah dipercaya memiliki kekuatan, baik struktur konstruksinya maupun adat kepercayaan setempat.

Setiap pengerjaan terhadap penyelesaian struktur konstruksi bangunannya, tentunya tidak terlepas dari pemahaman secara alamiah masyarakatnya dalam menanggapi setiap permasalahan bagian-bagian konstruksinya terhadap kepercayaan 
setempat. Pemahaman berarsitektur dalam struktur konstruksinya, merupakan pemahaman secara turun-temurun dalam setiap proses penyelesaian struktur konstruksinya, yang tentunya sesuai dengan nilai-nilai aturan adat kepercayaan setempat. Demikian pula pemahaman akan terselenggaranya bentukan-bentukan bangunan arsitekturnya dimaknai sebagai sesuatu yang terbentuk dari akibat adanya hubungan kekeraban bangsa dari wilayah lain dalam Nusa Tenggara Timur, yang kemudian disesuaikan dengan kekerabatan secara suku dalam wilayah Sabu sehingga terbentuknya bagian-bagian struktur konstruksi yang serupa namun sedikit berbeda perletakan dan ornamen-ornamen konstruksinya.

Tujuan penelitian ini untuk mengidentifikasi dan menganalisis cerminan lokalitas dalam berarsitektur sebagai pengetahuan masyarakat secara turun-temurun dalam memahami struktur konstruksi dengan memperhatikan nilai-nilai budaya serta kepercayaan masyarakat setempat.

\section{Bahan dan Metode}

Dalam penyelesaian teknologi membangun rumah, bentuk serta model bangunannya lebih cenderung memilih bentuk rumah bertiang atau di atas tiang (pile dwelling) dengan sistem sambungan yang memanfaatkan material lokal dari jenis material lokal setempat mulai dari material pondasi, dinding dan atap serta alat penyambung konstruksinya (Koentjaraningrat, 2009). Arsitektur merupakan sebuah karya yang bukan merupakan kebutuhan mendasar akan bangunan fisik saja, tetapi dilandasi oleh perhitungan-perhitungan rasional, dan arsitektur ini dapat menciptakan hubungan secara vertikal dengan penciptanya, dan spiritual antara manusia dengan alam semesta, serta hubungan sosial budaya antara sesama (Bano et al, 1992). Material memiliki perlakuan khusus dalam proses perangkaian untuk kontruksi (Frick, 1988).

Penelitian ini menggunakan deskriptif kualitatif dengan pendekatan secara etnografi.

\section{Hasil Pembahasan}

\subsection{Gambaran umum lokasi}

Wilayah yang merupakan tempat objek penelitian ini dilakukan, yakni Sabu Seba tepatnya berada di Kecamatan Sabu Barat dengan Delapan Belas Wilayah Desa, salah satunya Raeloro tepatnya berada di Wilayah Utara dari Pulau Sabu. Desa Raeloro sebagai tempat terletaknya Kampung Adat Namata berbatasan langsung dengan Desa Mebba, Desa Roboaba, Desa Ledeana, Desa Raenyale, dan Desa Nadawawi.

\subsection{Peradaban kekerabatan suku Sabu}

Anggapan masyarakat tentang asal mula nenek moyang bangsa sabu kemudian diluruskan oleh Kaho, [2000] dalam buku berjudul "HOLE" mengatakan dalam tulisannya yang berjudul "Orang Sabu dan Budayanya", terdapat indikasi yang kuat akan kesamaan Suku Sabu dengan Bangsa Melayu terlihat dari penggunaan lafal bahasa. Demikian pula halnya dengan penuturan dalam bahasa syair oleh masyarakat Betun memiliki kesamaan.

Diutarakan pula bahwa negeri asal orang - orang Betun (Belu), Sawu (Sabu), dan Orang Thie (Rote) adalah yang berasal dari Negeri India muka, yang bermigrasi dan 
singgah melalui Malaka atau Negeri Cina Melayu lalu ke Jawa kemudian menuju ke wilayah bagian Timur Indonesia dan menempati beberapa wilayah di daerah Nusa Tenggara Timur sampai berakhir pada wilayah bagian selatan Betun.

Kemudian kelompok ini menyebar dan memilih menetap dibeberapa temapt, seperti Belu Mau menetap di Betun atau Belu, Sabu Mau dan Thie Mau terus melanjutkan perjalanan menuju kearah barat kemudian Thie mau memilih untuk menetap di wilayah Rote, dan Sabu Mau terus melanjutkan perjalanannya hingga ke Raijua kepulauan Sabu. Setibanya Sabu Mau di wilayah Raijua, tempat ini sama sekali belum berpenghuni dan tidak memiliki rumah. Muncul pemikiran oleh bangsa ini untuk menggunakan perahu yang dipakai untuk dijadikan sebagai tempat berlindung dari hujan dan panas. Seperti yang pernah diutarakan oleh Muchtar, (2013) bahwa Nenek Moyang suku Ende Lio pertama kali tiba menggunakan perahu layar, demikian pula dengan kehadiran nenek moyang suku Sabu dengan kehidupan mereka sebagai pelaut.

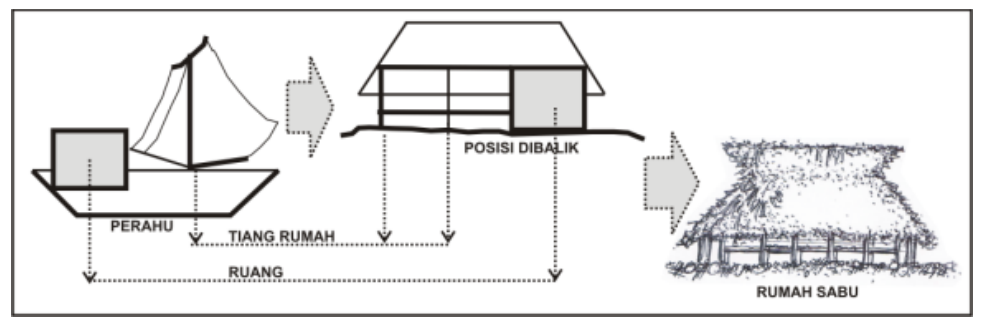

Pemahaman tentang filosofi rumah Sabu.

\subsection{Hasil migrasi dan peradaban yang membentuk kesamaan fisik}

Kesamaan ciri bentuk arsitektur pun terlihat dari bentuk pengaruh arsitektur Proto Mongoloid dan Caucasoid, dan juga pengaruh Proto Negroid dan Austroloid terhadap bentukan arsitektur yang ada di wilayah Nusa Tenggara Timur yang pernah diuraikan oleh kelompok kerja Tim Arsitektur Widya Mandira Kupang oleh Bano et al, [1992], bahwa perkembangan arsitektur pengaruh Proto Negroid dan Austroloid, yakni berupa bangunan tradisional Atoni Meto bertiang tunggal berdek pada bagian atas. Kemudian tiang ganda atau bercabang dengan tiang empat dan berdek pada bagian atasnya, menyerupai arsitektur Belu (Betun). Migrasi dari peradaban bangsa - bangsa Mongoloid terhadap arsitektur, yakni berupa arsitektur Caucasoid dan Mongoloid menghasilkan arsitektur dengan ciri berdek atau memiliki kolong atau panggung, seperti pada arsitektur Belu.

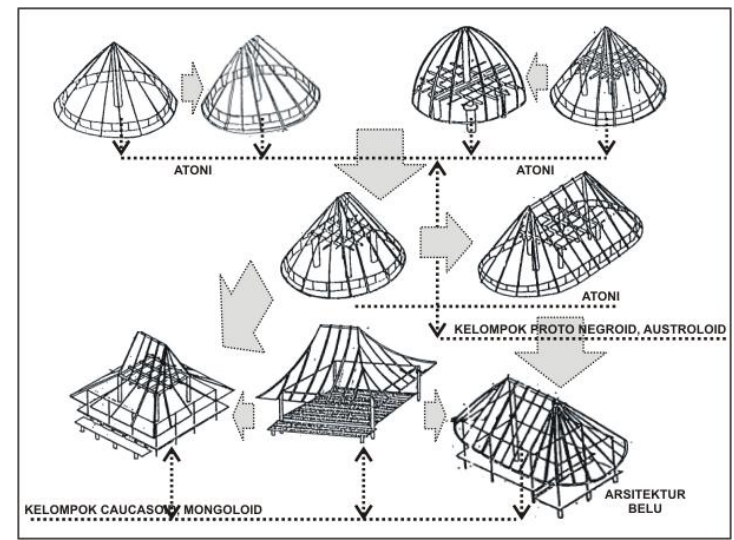


hasil peradaban menjadi ciri rumah panggung Belu.

Sumber : Bano et al (1992)

Demikian dengan cerita yang berkembang dan diutarakan oleh Kaho, [2000] tentang asal mula keberadaan nenek moyang orang Betun. Sabu dan Rote berasal dari Melayu, memiliki keterkaitan ciri secara fisik terhadap bangsa-bangsa Caucasoid dan Mongoloid oleh Bano et al (1992). Demikian pula penuturan oleh Timo (2014) bahwa bentuk rumah berhala Orang Sabu berbentuk seperti halnya rumah Orang Peking dan Nanking yang terdapat di Kota Baarn. Terlihat jelas dari bentuk atap rumah tradisional di daerah Betun (Belu) serta di Pulau Sabu, dengan kesamaan bentuk fisik sesuai pemahaman secara turun-temurun berupa rumah berciri panggung atau dek dan beratapkan bulat seperti halnya rumah tradisional Sabu, namun sedikit berbeda dengan rumah tradisional Belu, rumah tradisioanal Sabu pada bagian ujung atap terdapat daun leher.

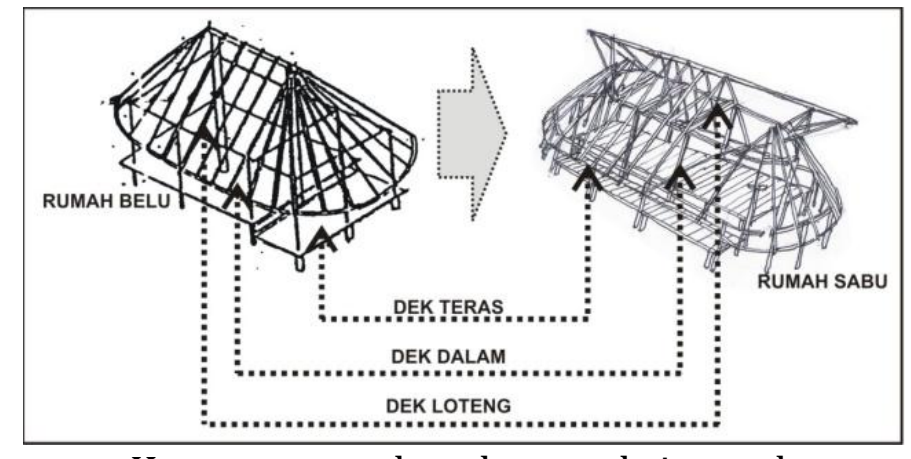

Kesamaan struktur konstruksi rumah

Belu (Betun) dan Sabu berciri panggung.

\subsection{Rumah tradisional Ammu Rahi Hawu}

Ammu Rahi Hawu merupakan salah satu bangunan tradisional masyarakat Sabu yang oleh masyarakat Sabu atau sering disebut juga sebagai Ammu Hawu atau rumah Sabu. Diyakini sebagai rumah pertama orang pertama yang menetap di Pulau Sabu yang disebut dengan nama Kika Ga. Kika Ga hidup berpindah kemudian menetap di wilayah Sabu Barat atau Sabu Seba, yang awalnya hanya mengenal daun Kole (Jenis daun lontar) sebagai media untuk membuat tempat berlindung. Kemudian seiring perkembangan, Kika Ga mulai mengenal beberapa bahan sebagai bagian yang akan dijadikan sebagai material konstruksi rumah dengan model rangka konstruksi yang secara turuntemurun dikenal hingga saat ini. Dan oleh masyarakat Sabu Seba kemudian beranggapan bahwa rumah ini merupakan rumah induk dari nenek moyang Kika Ga sampai pada keturunan Robo A'bba yang menghasilkan empat suku besar, yakni suku Namata, suku Nataga, suku Nahoro dan suku Nahupu.

Ruangan pada rumah tradisional Ammu Rahi Hawu, yakni terdapat ruang lakilaki (Duru), ruang tengah bagi kaum perempuan (Kopo) dan ruang perempuan berupa tempat aktivitas bagi kaum perempuan (Wui).

Struktur konstruksi rangka tiang secara umum, sering disebut dengan Ammu Halla (rumah tanam). Pemahaman ini terlihat dari beberapa bagian struktur tiang utama tiang pendukung lainnya, tertancap pada tanah dengan kedalaman tertentu 
berfungsi sebagai penopang struktur dek loteng (Dammu) dan tiang-tiang rangka atap serta bubungan. Sistem struktur rangka utama, atau tiang penopang struktur utama rumah memiliki jumlah 6 (enam). Terdiri pula dari beberapa elemen struktur pendukung lainnya, yakni 4 (empat) buah tiang Gerri Tebeka Keriu, tiang struktur penyokong balok dek pelengkung berjumlah 2 (dua) buah tiang Gerri Tebeka Duru, serta Struktur utama lainnya, yakni tiang dek ruangan (Gerri Kelaga Dara) dan tiang dek teras (Gerri Kelaga Rai) serta tiang penopang tritisan dari rangka atap (Gerri Tie Rou).

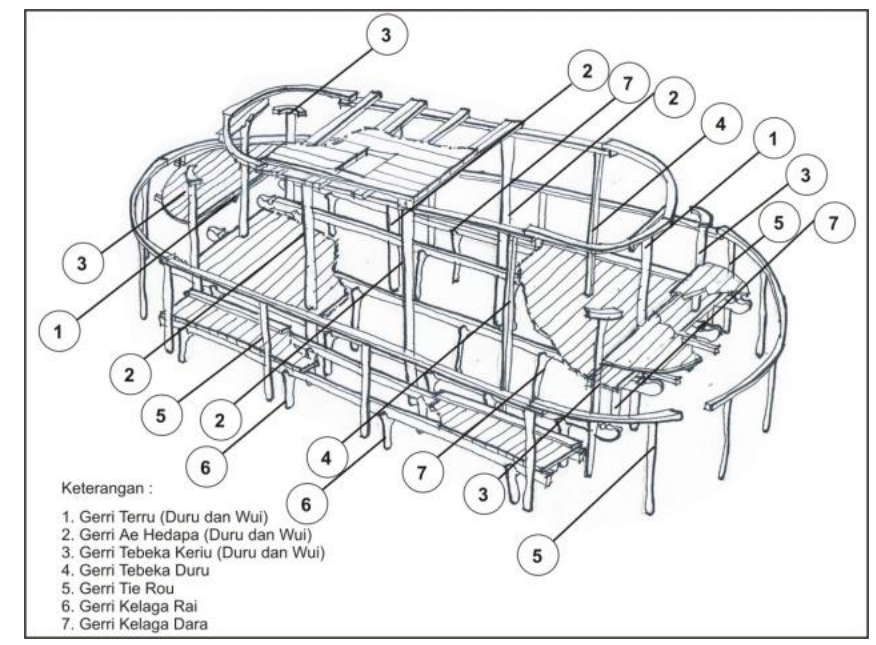

Gambar Model struktur rangka tiang Ammu Hawu.

Model pembalokan dan dek untuk rumah Rahi Hawu, terdiri atas pembalokan dek loteng, pembalokan dek ruangan dan pembalokan dek teras. Pembalokan dek loteng (Dammu), terdiri dari balok utama pada bagian kiri kanan (utara dan selatan) (Kebie Dida), balok dek Loteng (Tuki Dammu) dan dek loteng (Dammu) dan struktur balok pelengkung terdapat pada ujung-ujung rumah, berfungsi sebagai pembentuk lengkungan untuk rangka atap dan penopang struktur rangka atap pelengkung. Pelengkung atap ini dikenal sebagai Taga Batu. Model balok dan dek lainnya, yakni balok tritisan (Kebie Tie Rou), balok pelengkung tritisan (Heru Kelaga Rai), balok dek lantai ruangan (Tuki Kelaga Dara), dek lantai ruangan (Kelaga Dara), balok dek lantai teras (Tuki Kelaga Rai), dek lantai teras (Kelaga Rai), dan balok dek tempat penyajian (Tuki Udu Ketti).

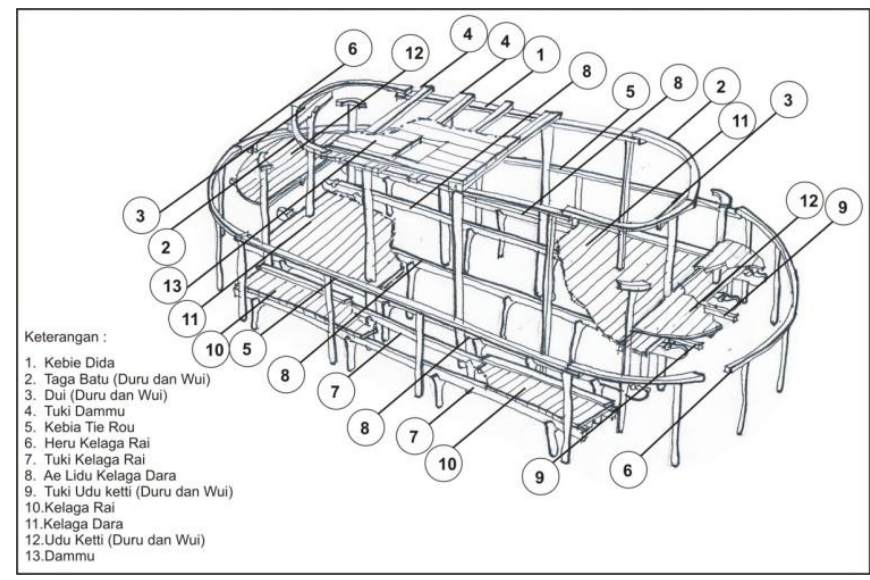


Gambar Model struktur rangka balok dan dek Ammu Hawu.

Struktur rangka atap di topang oleh 4 tiang (Kijuaga) penopang nok bubungan (Bangngu), Kaso atas (Worena), kaso depan dan belakang rumah, diteruskan sampai hampir mendekati tanah pada tritisan depan dan belakang (Worena Horo), dan kaso pada tritisan pelengkung (Worena Rukoko). Masing kaso (Worena), ditandai dengan bentuk buntalan sebagai pertanda akan pangkal bawah batang pohon yang digunakan pada konstruksi ini, yakni pangkal batang pohon Lontar.

Bagian reng (Badu) sebagai pengikat daun rumah (Bo'ro Ammu), kayu reng khusus pada bagian pelengkung (Badu Keware) diambil dari batang kayu Lamtoro Gum. Untuk penutup bubungan digunakan anyaman daun Lontar disebut Rupelila.

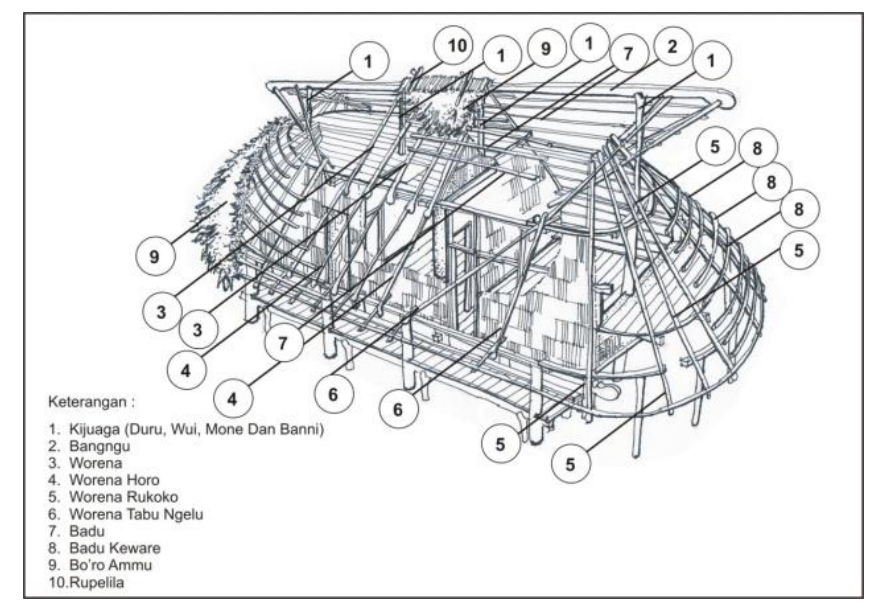

Gambar Model struktur konstruksi rangka atap Ammu Hawu.

\section{Sistem Teknologi}

\section{a. Sambungan}

Model sambungan konstruksinya menggunakan sistem tumpuk dengan coakan pada bagian - bagian elemen struktur. sistem sambungan lainnya menggunakan sistem coak, sambungan bibir lurus, takikan dan tali pengikat (Dari dan Pipa).

\section{b. Bahan material konstruksi}

Jenis bahan material untuk sebuah rumah Ammu Rahi Hawu masih berasal dari lokasi sekitar pembangunan rumah tersebut. Dengan beberapa material yang dipilih khusus tentunya untuk bagian - bagian konstruksi yang berhubungan langsung dengan tanah seperti bahan tiang (Gerri), yakni menggunakan material dari jenis kayu Kolla. Selain jenis kayu Kolla juga digunakan kayu jenis Lontar untuk bagian - bagian konstruksi Balok (Tuki dan Ae Lidu), dek lantai (Kelaga Rai dan Dara), nok (Bangngu), setiap kaso (Worena), dan sebagian reng (Badu) serta sebagian reng pelengkung (Badu Keware) digunakan kayu jenis Lamtoro gum. Untuk jenis material tali pengikat terbuat ari rautan pelepah batang daun pohon Lontar terdiri dari dua jenis, yakni Dari terbuat dari rautan pelepah daun pohon lontar yang kemudian dipintar atau dikenal dengan tali besar, Pipa merupakan tali dari rautan pelepah batang daun pohon Lontar tanpa pintalan. 
Untuk jenis material penutup atap dan dinding, digunakan material dari jenis daun Lontar yang dianyam dengan diberi pengapit dari jenis material kayu pohon Pinang.

\section{Kesimpulan}

Lokalitas bangunan dapat terlihat dari model struktur konstruksi yang tertuang dalam unsur budaya, yakni bahasa, pengetahuan, teknologi dan kesenian. Penilaian secara fisik dapat memperoleh makna tentang kedudukan sosial dalam struktur organisasi adat serta fungsi bangunan. Lokalitas tercermin pada salah satu unsur dalam kebudayaan, yakni teknologi yang mencakup sistem sambungan, material serta ornamen bangunan arsitekturalnya.

\section{Daftar Pustaka.}

Bano R. M. Z., Betang A. Y., Fernandez R., Bell J., Fanggidae L., Toka E., Herewila J., Manu A. K., Titi Ch. 1992. Laporan Studi Arsitektur Proto mongoloid - Negroid Austroloid, Kelompok Kerja Arsitektur Vernakuler. Universitas Widya Mandira Kupang - Nusa Tenggara Timur

Frick H. 1988. Arsitektur dan Lingkungan, Penerbit Kanisius cetakan pertama 1988. "HOLE", Ritual Budaya Masyarakat Sabu. Percetakan PNRI Cabang Kupang, Penerbit Biro Humas Setda Provinsi Nusa Tenggara Timur 2000.

Koentjaraningrat. 2009. Pengantar Ilmu Antropologi. Penerbit Rineka Cipta.

Kaho R. R. 2005. Orang Sabu dan Budayanya. Yogyakarta: Penerbit Jogja Global Media.

Muchtar M. A. 2013. Tradisi Proses Pembangunan Kembali Bangunan Tradisional Sao Keda Suku Ende Lio Flores Di Desa Wolotolo. Tesis. Malang: Universitas Brawijaya, Arsitektur Lingkungan Binaan.

Timo E. I. N. 2014. Sabu Punya Cerita. Injil di Rai Due Nga Donahu 100 Tahun Lalu. Yogya: Satya Wacana Univercity Press 